\title{
Bakhtin and the Kierkegaardian Revolution
}

Sergeiy Sandler

Note: The text below, completed in January 2012, was originally meant to be a standalone article, but did not get published at the time, and my own thinking on the subject has evolved somewhat since. I'm currently revising it to be incorporated in a book-length philosophical reading of Mikhail Bakhtin's work. Nevertheless, this older version can perhaps be of use to readers. I'd also be glad to receive feedback on the text (at sergeiys@gmail.com)

\begin{abstract}
Søren Kierkegaard's influence on the thought of Mikhail Bakhtin has received relatively little attention from Bakhtin scholars (and hardly any attention from Bakhtin scholars in the English-speaking world). Yet, as I argue in this paper, Kierkegaard was among the most important formative influences on Bakhtin's work. This influence is most evident in Bakhtin's early ethical philosophy, but remains highly relevant in later periods. Reading Bakhtin as a follower and developer of Kierkegaard's fundamental philosophical insights provides us with a key to the unity of Bakhtin's thought.
\end{abstract}

One may divide the reception of the work of the Russian thinker Mikhail Mikhailovich Bakhtin into three waves. At first it was assimilated to familiar paradigms (Marxism, structuralism, poststructuralism, etc.) ${ }^{1}$ The second wave emphasized Bakhtin's originality as a thinker, ${ }^{2}$ but was also prone to overstate it. The third wave, which extends to the present time, reacted with a more careful scholarly approach, focusing on the sources of influence on Bakhtin's thought, ${ }^{3}$ but this scholarly precision sometimes came at the expense of understanding what is truly new in Bakhtin's work. However, as Bakhtin himself stressed, a truly original utterance is original by virtue of how it incorporates within it the voices of those who spoke before. The role played by Bakhtin's sources of influence on forming his original thought has often been neglected or deeply misunderstood.

In this paper I focus on one particular source of influence on Bakhtin's thought, though, as I shall argue, an especially important one: the Danish philosopher Søren Aabye Kierkegaard.

${ }^{1}$ Typical examples are: Kristina Pomorska, Preface to Mikhail Bakhtin, Rabelais and His World (hereafter Rab.), trans. Hélène Iswolski (Cambridge: MIT Press, 1968), v-x; Julia Kristeva, "Préface: une poétique ruinée,” in Mikhail Bakhtine, La poétique de Dostö̈evski (Paris: Éditions du Seuil, 1970), 5-29, and cf. Galin Tihanov, "Mikhail Bakthin: Multiple Discoveries and Cultural Transfers," Wiener Slawistischer Almanach Sonderband 78 (2010): 45-58.

${ }^{2}$ E.g. Katarina Clark and Michael Holquist, Mikhail Bakhtin (Cambridge, Harvard University Press, 1984).

${ }^{3}$ E.g., Craig Brandist, The Bakhtin Circle: Philosophy, Culture and Politics (London: Pluto Press, 2002). For a programmatic statement see: Peter Hitchcock, "The Bakhtin Centre and the State of the Archive: An Interview with David Shepherd," South Atlantic Quarterly 97 (1998): 753-72. 
I shall argue that Kierkegaard's philosophy, especially his notion of existence and the reversal of traditional philosophical and metaphilosophical priorities it embodies, is crucial to understanding Bakhtin's work, its originality, and its internal continuity.

Bakhtin is notorious for rarely mentioning his sources of influence explicitly in his writings, and Kierkegaard, too, is mentioned in extant texts only three times, in passing (although in telling contexts). ${ }^{4}$ Nevertheless, we do have a direct testimony to the importance of Kierkegaard in the formation of Bakhtin's philosophical outlook. In an interview recorded in 1973, Bakhtin vividly recounts how he became acquainted, indeed infatuated, with the writings of the Danish philosopher. ${ }^{5}$ Bakhtin was introduced to Kierkegaard by the Swiss writer Hans Limbach, who lived in Russia at the time. ${ }^{6}$ Impressed by this first encounter, Bakhtin acquired and read a multi-volume German translation of Kierkegaard's work. All this happened in 1913, an early stage not only in Bakhtin's intellectual development (he was 17), but also in Kierkegaard's reception in European philosophy. Sixty years later, Bakhtin still kept up with publications about Kierkegaard in Russian.

Kierkegaard's influence on Bakhtin has met with surprising silence from Bakhtin scholars. To the best of my knowledge, apart from fleeting references, there is only one article published in English on the topic. ${ }^{7}$ In other languages, especially Russian, the situation is somewhat better, ${ }^{8}$ but as important and informative as these contributions are, they do not, in

${ }^{4}$ Mikhail Bakhtin, "Author and Hero in Aesthetic Activity” (hereafter AH), in Art and Answerability, trans. V. Liapunov (Austin, 1995), 20; Mikhail Bakhtin, Sobranie sochinenij (Moscow: Jazyki slavianskikh kul'tur, 1996-2012), hereafter Sobr., 1: 101; Rab, 120; Sobr., 4(2): 133; "Menippova satira i ee znachenie v istorii romana," in Sobr., 4(1): 740; see also: AH, 118; Sobr., 1: 190. All references to Bakhtin's works are cited both in the Russian original and in English translation, where available.

${ }^{5}$ Mikhail Bakhtin, Besedy s V. D. Duvakinym (Moskva: Soglasie, 2002), 41-43.

6 Vadim Liapunov, "V prodolzhenie kommentarija k 'Avtoru i geroju v esteticheskoj dejatel'nosti.' Primechanie 109: Kirkegor," in “Literaturovedenie kak literatura”: Sbornik v chest' S. G. Bocharova, ed. I. L. Popova (Moscow: Jazyki slavianskoj kul’tury, 2004), 425-26.

7 Alex Fryszman, “Kierkegaard and Dostoyevsky Seen Through Bakhtin's Prism,” Kierkegaardiana 18 (1996): 100-125. See also: Tapani Laine, "Back to Bakhtin" (presentation, $11^{\text {th }}$ International Mikhail Bakhtin Conference, Curituba, Brazil, July 21-25, 2003); "Back to Bakhtin 2" (presentation, 12 ${ }^{\text {th }}$ International Mikhail Bakhtin Conference, Juväskyla, Finland, July 18-22, 2005).

${ }^{8}$ Alex Fryszman, “Teoriia kommunikatsii Serena K'erkegora i dialogicheskoe myshlenie Bakhtina,” Wiener Slawischer Almanach 31 (1993): 39-55; “O Serene K'erkegore i Mikhaile Bakhtine 's postoiannoj ssylkoj na Sokrata'," in Mir K'erkegora, ed. Aleksej Frishman [Alex Fryszman] (Moscow: Ad Marginem, 1994), 106-22; "Ia i drugoj. Kritika romanticheskogo soznaniia u Bakhtina i K’erkegora," Russian Literature 38 (1995): 273- 
my view, reveal the true nature and full extent of Kierkegaard's influence on Bakhtin. This influence, I shall argue, goes to the very heart of Bakhtin's philosophical motivation, and reading Bakhtin in this light allows for a deeper and clearer understanding of his thought.

There are many notable similarities between the two thinkers' positions. Nevertheless, what Bakhtin took from Kierkegaard were not so much specific claims and ideas, as a more basic metaphilosophical approach, which puts the human individual's position in, and engagement with, the world above objective givenness and impersonal truth. And it is from this Kierkegaardian starting point that Bakhtin sets out on his own scholarly journey, a journey that often leads him well beyond the positions advocated by Kierkegaard himself, but on which he remains true to the radical metaphilosophical shift initiated by Kierkegaard.

\section{What Is the Kierkegaardian Revolution?}

Søren Kierkegaard belonged to a generation of European thinkers who had a crucial influence on the development of modern philosophy. I will refer to it as the post-Hegelian generation, not only because it followed Georg Wilhelm Friedrich Hegel in time, but also because responding to Hegel's philosophical system, as they interpreted it, was a central project for these thinkers. They were significantly influenced by Hegel's work but ultimately rejected it. (By using the term "post-Hegelian" I am consciously overstating the role played by Hegel

94; "Den andens stemme: Michail Bachtin og Søren Kierkegaard med særligt henblik på subjektivitetens problem," in Smuthuller: perspektiver i dansk Bachtin-forskning, ed. Nina Møller Andersen and Jan Lundquist (Kopenhagen: Politisk revy, 2003), 153-70; "Bakhtin e Kierkegaard. Sulle tracce del pensiero dialogico. La scoperta di Kierkegaard da parte di Mikhail Bakhtin," NotaBene. Quaderni di Studi Kierkegaardiani 3(2003): 159-81; Tatiana Schittsova, “K ontologii chelovecheskogo bytiia (Kirkegor i Bakhtin),” Dialog. Karnaval. Khronotop 12 (1995): 34-42; “Chelovek—dialog—kul’tura (k ontologii kul'tury v ekzistentsial'noj filosofii Kirkegora i Bakhtina)," Mezhdunarodnye chteniia po teorii, istorii i filosofii 2 (1997): 241-48; K istokam ekzistentsial'noj ontologii: Paskal', Kirkegor, Bakhtin (Minsk: Propilei, 1999); “Der Idee der 'antwortenden Subjektiviät' im Werk von Søren Kierkegaard und Michail Bachtin,” in Diskurse der Personalität, ed. Alexander Haardt and Nikolaj Plotnikov (Paderborn: Fink, 2008), 241-50; Tatiana Schittsova (ed.), Kirkegor $i$ sovremennost' (Minsk: RIVSHiGO, 1996); Alexander Haardt, "Ethische und ästhetische Persönlichkeit. Zum Verhältnis des Ethischen und Ästhetischen bei Sören Kierkegaard und Michail Bachtin,” Studies in East European Thought 61 (2009): 165-79. See also: Vitalij L. Makhlin, Filosofskaia programma M. M. Bakhtina $i$ smena paradigmy v gumanitarnom poznanii (Moscow: MPGU, 1997); Elena Bogatyreva, "Estetika v filosofskoj sisteme Bakhtina" (diss., Moscow State University, 1991); Edward Kasperski, Dialog i dialogizm. Idee, formy, tradycje (Warsaw: Dom Wydawniczy ELIPSA, 1994); Kierkegaard: antropologia i dyskurs o czlowieku (Pultusk: WSH, 2003). I am grateful to Tapani Laine, Danuta Ulicka, and Elena Bogatyreva for providing me with information on many of the references in the last two notes. 
himself, as towering a figure as he was; other thinkers made important contributions to the positions post-Hegelianism reacted against, which are also relevant to the aims of the present paper, ${ }^{9}$ but a focus on Hegel does make for a clearer exposition of the issues at stake; Hegel's name is used here symbolically, somewhat like Descartes' name is, when speaking broadly of modern philosophy as "Cartesian").

Hegel's philosophy is notoriously difficult and a brief exposition cannot possibly do it justice. Nevertheless, I will try to touch on a few central points, as a necessary background for the rest of the discussion.

Hegel was a systematic idealist philosopher, i.e. he sought to provide a unified philosophical account of consciousness and, through it, of the world. In the Phenomenology of Spirit,${ }^{10} \mathrm{Hegel}$ introduced his system by presenting and describing what he called Absolute Spirit. To borrow a few metaphors from the exact sciences, Absolute Spirit is like a fourdimensional fractal object (or rather subject ${ }^{11}$ ). It is four-dimensional in the sense that it includes within itself not only its final (three-dimensional) form, but also the entire historical process of its development. ${ }^{12}$ It is fractal in the sense that the entire structure and development of Absolute Spirit is the result of the reiteration of a simple operation, which is for Hegel also the essence of human consciousness and the main building block of his new science of logic: the activity of negation. ${ }^{13}$

Propelled by the force of negation, consciousness commences on a journey, at once historical and epistemological, from the immediate givenness of the objects of perception as not-itself to eventually recognizing itself in the world and its history. On this journey it moves from sense perception, through social relations, various historical forms of social order, reason, and religion, to an eventual state of scientific-philosophical knowledge, in which it possesses a system of science that accounts for all of these as belonging to consciousness itself.

\footnotetext{
${ }^{9}$ See, e.g., Fryszman, "Ia i drugoj."

${ }^{10}$ Georg Wilhelm Friedrich Hegel, Phenomenology of Spirit (hereafter PS, cited by paragraph number), trans. Arnold Vincent Miller (Oxford: Clarendon Press, 1977).

${ }^{11}$ Ibid, $\$ 17$.

${ }^{12}$ Ibid, $\$ 12$.

${ }^{13}$ Ibid, $\S 18$.
} 
As Jon Stewart notes, ${ }^{14}$ the notion of system in German idealism implies an organic unity. Indeed, for Hegel, the organic unity of his system of science subsumes under it the seeming contradictions produced by the negating activity of consciousness. Eventually, consciousness recognizes itself as an organic unity which comprises the world. The subject is an organic unity, living in the organic unity of a social order, which has developed through the organic unity of history, and now allows for absolute scientific knowledge which coincides, also as an organic unity, with revealed religion. Like the plant Hegel himself uses as a metaphor, ${ }^{15}$ his entire philosophical system, in all its different and seemingly incompatible historical forms, is a whole in which every part and stage is necessary.

Thinkers of the post-Hegelian generation formed their philosophical outlooks at a time when Hegel's system was considered an unsurpassed achievement. Indeed they all absorbed much from Hegel. But it was precisely the all-encompassing nature of the Hegelian system, its claim to be the ultimate totality of philosophical truth, which posed for them with the utmost clarity a new kind of philosophical question: the question about the point of this exercise, and by extension, of philosophizing. One answer to this question was succinctly formulated by Karl Marx in 1845: "The philosophers have only interpreted the world, in various ways; the point is to change it." 16 Ten years earlier, Kierkegaard, the other great postHegelian, wrote this oft-quoted passage in his journal:

What I really need is to get clear about what I must do, not what I must know, except insofar as knowledge must precede every act. What matters is to find a purpose, to see what it really is that God wills that $I$ shall do; the crucial thing is to find a truth which is truth for me, to find the idea for which I am willing to live and die. ${ }^{17}$

${ }^{14}$ Jon Stewart, "Hegel's Phenomenology as a Systematic Fragment," in The Cambridge Companion to Hegel and Nineteenth-Century Philosophy, ed. Frederick C. Beiser (Cambridge: Cambridge University Press, 2008), $76-78$.

${ }^{15} \mathrm{PS}, \S 2$.

${ }^{16}$ Karl Marx, "Concerning Feuerbach," in Early writings, trans. Rodney Livingstone and Gregor Benton (Harmondsworth: Penguin Books, 1992), 423.

${ }^{17}$ Søren Aabye Kierkegaard, Søren Kierkegaard's Journals and Papers. Vol. 5, Autobiographical, 18291848, trans. Howard Vincent Hong, Edna Hatlestad Hong and Gregor Malantschuk (Bloomington: Indiana University Press, 1978), 34. 
Kierkegaard then goes over the parts of Hegel's system - the history of philosophy, the state, religion, and truth itself - and asks the same question about each of them: What is the point of knowing these things from his own subjective perspective? ${ }^{18}$

This passage is, however, easy to misunderstand. Kierkegaard does not merely draw a distinction between knowledge and action, or between secular knowledge and religious faith, or between the objective and the subjective. Nor does he simply favor one side of these dichotomies over the other. After all, had he had a complete theory of action, of religion, of the subject, he would still be thus "constructing a world [he] did not live in but merely held up for others to see."19

Kierkegaard wants a kind of philosophy that would tell him not what he must know but what he must $d o$. Well, is not "What must one do" the central question of ethics? Yes. And indeed, the ethical occupies a central place in Kierkegaard's philosophy. But traditionally, ethics seeks to derive the answer to the question "What must one do" from general principles, i.e., from the answer to the question "What must one know." Nor is it a coincidence that ethics asks "What must one do," while Kierkegaard asks "What must $I$ do." For Kierkegaard the question, "What must I do" cannot be reduced to the question, "What must anyone in my position do," nor even to the question, "What must anyone like me do in my position." Religious duty is deeply individual and cannot be generalized into a rule.

But Kierkegaard's main philosophical innovation is more essential still. It has to do, as I already noted, with philosophy's purpose: to answer the demands not of objective knowledge about things in the world but of the individual person with her unique perspective, with what truly matters to her. Again, it is easy to miss Kierkegaard's point. Isn't subjectivity central to all modern philosophy, from Descartes on? It is, but not for its own sake. For Descartes, subjective self-knowledge is a means to avoid error. Possessing the truth about reality is of intrinsic value; what this truth and this reality mean to the individual is not. Hegel's Phenomenology of Spirit tells a story whose main protagonist is human consciousness, but the individual consciousness matters to Hegel where and when it eventually conforms to the logical scheme he proposes. Kierkegaard, on the other hand, while not disputing the truth of

\footnotetext{
${ }^{18}$ Kierkegaard, Journals 5, 34-35.

${ }^{19}$ Ibid.
} 
objective knowledge and the validity of logic, ${ }^{20}$ claims philosophical primacy for the moral concerns and the first-person perspective of the concrete human individual.

This is, in fact, no less than a philosophical revolution. At least since Parmenides, it has been taken for granted by philosophers that what is constant underlies what is changeable. A substance is what remains the same when a thing undergoes change; objective truth is what holds equally well for any person. Even most subjectivists and relativists accept this order of priority, that is to say, they do not deny the primacy of what remains constant and holds for all over what is subjective, changing, or relative; they merely deny that there is anything that can attain this higher status. What Kierkegaard proposes, on the other hand, is that an individual's attitude to reality, to her life, ultimately to God, differs sharply from one person to another, but at the same time, it is in this realm of inwardness, that the highest philosophical and religious truth resides. Whatever is common to all people is not denied, but deemed less important.

This point is further developed when Kierkegaard discusses his version of the distinction between existence (esse) and possibility (posse), or between the actual and the potential. ${ }^{21}$ What is conceived of in thought is merely possible or potential. But my own existence and my own acts are actual for me. An actual act goes beyond all thought, beyond the question of what would performing such an act mean to such a person as myself. It is no longer a matter of the mere possibility of acting in a particular way; it is the thing itself. This simple gap between the act itself and the potential content assigned to it by thought is a gap that thought can pretend to ignore, but cannot bridge. ${ }^{22}$ Objective truth and knowledge can supply me with potentialities, with descriptions of how things might be. Actually living through the thing itself is a different matter altogether. This actuality is beyond the reach of mere knowledge, beyond the reach of general principles. Knowing what to do does not yet mean doing it; acknowledging a truth does not yet mean truly accepting it. $^{23}$

${ }^{20}$ M. G. Piety, "The Reality of the World in Kierkegaard's Postcript," in International Kierkegaard Commentary, Vol. 12: Concluding Unscientific Postscript to “Philosophical Fragments, ” ed. Robert L. Perkins (Macon: Mercer University Press, 1997), 169-86.

${ }^{21}$ Søren Aabye Kierkegaard, Concluding Unscientific Postscript to Philosophical Fragments, trans. Howard Vincent Hong and Edna Hatlestad Hong (Princeton, NJ: Princeton University Press, 1992), 1: 318-43 (hereafter CUP).

\footnotetext{
${ }^{22}$ Ibid, $1: 323$.

${ }^{23}$ Ibid, 1: 22.
} 
Existence also means constant becoming. Any attempt to sum up an individual is doomed to failure, at least from that individual's own perspective. When summing up, one has to look back, but in existence one always moves forward. ${ }^{24}$ An individual may, at least on some occasions, decide to change herself, to overcome any given objective description. Any abstract notion of what people are in general, of what subjectivity is in general, fails precisely because of its generality. It offers no account of what my subjectivity means to $m e{ }^{25} \mathrm{~A}$ system (an organic unity) that contains individual existence in it is impossible, other than from God's perspective, ${ }^{26}$ because individual existence will always transcend it, will not allow the system to reach completeness.

Moreover, this process of constant becoming crucially involves what Kierkegaard called leaps. To make a leap is not merely to undergo change and development, because development can be immanent, a move from one state to the next can follow logically from what the first state involves and includes. But to make a leap means accomplishing a shift from one existential state to another, the possibility of which contradicts what defines the former state, a contradiction that cannot be subsumed under a higher systematic unity, at least not from the perspective of the person performing the leap.

Earlier I noted several times that Kierkegaard is easy to misunderstand. Why? Because a philosopher who takes as her starting point the postulates that Kierkegaard rejects will be blind to what he has to say. This is especially true when one subordinates one's entire philosophy to logic. Such an approach is prone to deny there is anything to the first-person perspective that does not fit into the logical scheme, precisely because it does not fit into it, or conversely, to pretend that the first-person perspective does fit the logical scheme, that is, to substitute a logical replica of subjectivity for the real thing. ${ }^{27}$

This approach can also be applied to Kierkegaard himself. One may easily cull some particular claims and arguments from Kierkegaard's writings and present those as his philosophy. After all, isn't philosophy all about propositions and arguments? But a proposition is true or false regardless of whether anybody holds it, rejects it, or is even aware of it. An argument moves from its premises to its conclusion regardless of whether anybody in fact argues it. Kierkegaard's own propositions and arguments, if taken to be mere

\footnotetext{
${ }^{24}$ Ibid, 2: 187.

${ }^{25}$ Ibid, 1: 120.

${ }^{26}$ Ibid, 1: 118-25.

${ }^{27}$ Cf. Ibid, 1: 123.
} 
propositions and arguments, are no different. Kierkegaard insists that the individual's attitude to the content of a proposition has priority over the content of the proposition in itself, indeed that it is in this relation that truth resides. But isn't this itself a proposition, the objective truth or falsity of which will now be a matter for philosophical discussion and debate? Such a meta-philosophical position, dooms Kierkegaard's project, if interpreted strictly within it, to failure, indeed to self-contradiction or to infinite regress (as the primacy of one's inward relation to this proposition is asserted, the assertion would itself be a proposition, and so on, ad infinitum). ${ }^{28}$ The key to understanding Kierkegaard's import to philosophy is to understand his main meta-philosophical point.

The philosophical primacy of existence over possibility, of subjective truth over objective truth, also led Kierkegaard to problematize the communicability of subjective truth. Communicating a proposition means stating it. But how does one communicate one's deep inner relation to a proposition? Claiming to hold a certain relation by explicitly stating what it is would only return us to the same question at one remove: how does one communicate one's deep inner relation to this latter statement? Was it stated in earnest or in jest? ${ }^{29}$ This is not to say that Kierkegaard thought communication of one's inner truth to be entirely impossible. Inwardness can, up to some degree, be communicated, but such communication has to be indirect. It has to pass through what Kierkegaard called "double reflection": the first reflection merely provides the objective content of the message; the second reflection relates this message to its utterer and to the receiver. It is this second reflection that can uncover (although this successful outcome is by no means guaranteed) the inner truth hidden within the message. ${ }^{30}$

Kierkegaard's own message was all but ignored by his contemporaries. He remained virtually unknown for decades after his death, and even now, as a classic of modern philosophy, he is still often misinterpreted. But in the remainder of this paper I will focus not on how he was misunderstood, but on how his thought was, I think, deeply and originally understood and appropriated by Mikhail Bakhtin. As I will show below, Bakhtin develops Kierkegaard's philosophical revolution in a most original and interesting way. Conversely,

${ }^{28}$ Cf. Ibid, 1: 333.

${ }^{29}$ Cf. Ibid, 1: 69-70.

${ }^{30}$ See, e.g., James Kellenberger, Kierkegaard, Indirect Communication, and Religious Truth, International Journal for Philosophy of Religion 16 (1984): 153-160. 
Bakhtin's own philosophy can only be deeply understood if his debt to Kierkegaard is acknowledged and kept in mind.

\section{Kierkegaard and Bakhtin's Philosophical Motivation}

There are many similarities between Kierkegaard's philosophy and Bakhtin's works. For example, both thinkers claim that only from God's perspective can an individual's existence be viewed as a totality. ${ }^{31}$ Both also distinguish between objective and subjective truth. ${ }^{32}$ Kierkegaard's notion of indirect communication is echoed in Bakhtin's and the Bakhtin Circle's theory of language, most notably in Bakhtin's notion of double-voiced discourse. ${ }^{33}$

These parallels (and others ${ }^{34}$ ) are striking, and they warrant scholarly attention, but they do not reach the full depth of Kierkegaard's influence on Bakhtin, an influence which has to do with the philosophical motivation these thinkers share, with how they understand the point of philosophizing. This motivation informs Bakhtin's work in all areas and in all periods, but it is especially evident in the surviving fragment of his earliest, unfinished, major work, toward a Philosophy of the Act (written most probably in the early $1920 \mathrm{~s}^{35}$ ). In this work, Bakhtin argues for a first philosophy ${ }^{36}$ at the center of which stand the act (or, to render it more precisely, the deed, postupok), and the event of being (sobytie bytiia). I shall discuss the event of being (the germ of what later was labeled "dialog"37) further below. Here I would like to focus on the notion of the deed, which is key to properly understanding Bakhtin's early philosophy.

${ }^{31}$ CUP, 1: 118; Nikolai Nikolaev (ed), “M. M. Bakhtin's Lectures and Comments of 1924-1925. From the Notebooks of L. V. Pumpiansky" (hereafter Lect.), trans. Vadim Liapunov, in Bakhtin and Religion: A Feeling for Faith, ed. Susan M. Felch and Paul J. Contino (Evanston: Northwestern University Press, 2001), 193-237; Sobr., 1: 328-30.

32 CUP, 1: 189-251; Mikhail Bakhtin, Toward a Philosophy of the Act (hereafter TPA), trans. Vadim Liapunov (Austin: University of Texas Press, 1993), 46; Sobr., 1: 43.

${ }^{33}$ Fryczman, “O K'erkegore i Bakhtine," 121; Schittsova, "Chelovek—dialog—kul'tura”. On double-voiced discourse see: Mikhail Bakhtin, Problems of Dostoevsky's Poetics (hereafter PDP), trans. Caryl Emerson (Minneapolis: University of Minnesota Press, 1984), 185-204; Sobr., 2: 81-101, 6: 207-228.

${ }^{34}$ For additional parallels see the works by Schittsova and Fryszman referred to above.

35 On the dating of Bakhtin's early works see Liudmila Gogotishvili, in Sobr., 1: 414-17; Nikolai Nikolaev and Vadim Liapunov, in Sobr., 1: 495-503 (commentary to Sobr. is cited by indicating the commentator(s) and page numbers only).

${ }^{36}$ TPA, 27-28; Sobr., 1: 28-29.

${ }^{37}$ See: Tatiana Schittsova, Sobytie v filosofii M. M. Bakhtina, Minsk: I. P. Logvinov, 2003. 
The title toward a Philosophy of the Act (given to this work by its publishing editors, as Bakhtin's original title is unknown) is potentially misleading. It suggests that this work is devoted to the philosophical exploration of a specific kind of phenomenon, the act/deed. But Bakhtin's actual aim was to approach the most basic philosophical questions; the deed is a way in which Bakhtin characterized the ultimate reality, as he understands it.

The deed is active, but it is not merely an action. It is intentional (and motivated ${ }^{38}$ ), but is not the same as an intentional act. ${ }^{39}$ It belongs to the realm of the ethical, but not merely in the sense of being related to mores and norms. ${ }^{40}$ While the word "deed" implies a particular action, Bakhtin uses it to refer to human existence more generally: "For my entire life as a whole can be considered as a single complex act or deed that I perform." ${ }^{41} \mathrm{He}$ also does not understand the deed as necessarily distinct from thought. ${ }^{42}$ A thought is as much a deed for Bakhtin as an action in the narrow sense, provided that it has actually been thought by an actual individual, it is a deed so long as it was indeed performed:

In other words, Bakhtin's notion of the deed is clearly parallel to Kierkegaard's understanding of existence. This becomes all the more obvious if we consider the deeply personal nature of the deed, as reflected even in the language of toward a Philosophy of the Act: instead of voicing claims in the third person about "the subject," "the self," "the I," Bakhtin typically uses the first person singular (this is not how the text is narrated, but how specific philosophical claims are made), emphasizing the unique and unrepeatable nature of personal experience and action: "That which can be done by me can never be done by anyone else." $" 43$

This personal actuality of the deed is not the product of the general form of the subject, of what anyone would experience and do in my place. Thought, as an actual deed, is prior to the general rules of logic: "The course from a premise to a conclusion is traversed flawlessly and irreproachably, for I myself do not exist upon that course."44 In this Bakhtin consciously challenges modern philosophy as such:

\footnotetext{
${ }^{38}$ TPA, 29; Sobr., 1: 29.

${ }^{39}$ Pace Brandist, Circle, 35.

${ }^{40}$ TPA, 5-6; Sobr., 1: 10.

${ }^{41}$ TPA, 3; Sobr., 1: 8.

42 Ibid.

${ }^{43}$ TPA, 40 (emphasis added); Sobr., 1: 39.

${ }^{44}$ TPA, 21; Sobr., 1: 23.
} 
All of modern philosophy sprang from rationalism and is thoroughly permeated by the prejudice of rationalism (even where it consciously tries to free itself from this prejudice) that only the logical is clear and rational, while, on the contrary, it is elemental and blind outside the bounds of an answerable consciousness, just as any being-in-itself is. ${ }^{45}$

Bakhtin explicates his notion of the deed using oppositions, such as those between the answerable deed and theory, participative thinking (uchastnoe myshlenie) and theoretism, life and culture, fact and content, subjective truth (pravda) and objective truth (istina), etc. The terms comprising these oppositions often appear interchangeable, but, in fact, they differ from each other in important senses. One such difference is that between theory and theoretism.

Theory is the product of the scientific study of objective reality. As such it is limited to the objective moment of deeds, to objective truth, and is unable to grasp the deed itself. To illustrate the point, consider a map of the world. The map is a theoretical representation of the Earth's surface. If we imagine that map to be large and detailed enough, it will be possible to locate in it the place in which I am now sitting and writing. But the way in which the map represents space is radically different from the way in which I now experience it. On the map (qua theoretical representation) all points are of equal value, but for my space there are at least two points that are privileged: the point from which I am observing the world and the point to which I am directing my attention. The map is also indifferent to the fact that some locations in space have special meaning for me: places that I intend to visit or wish to avoid, a place I call "home", etc. The map successfully captures all the objective properties and relations of the represented space, but space as it exists for me, while there is nothing in it that is incompatible with all those objective properties and relations, is not map-like. The map reflects valuable theoretical knowledge. It is also a useful artifact. But theory, precisely because it provides objective knowledge, just cannot grasp what I see right now and how I see it, nor can it tell whether there is anybody looking at the world from this vantage point I am occupying or not.

Nor will more theory make any difference. If we augment geography with optics or even psychology, we will still have no access to how I experience the world and act in it.

${ }^{45}$ TPA, 29; Sobr., 1: 30. 
Theoretical knowledge for Bakhtin is potential: it tells us much about what a person would experience if she did this or that, but cannot replace the actual deed and experience.

In arguing so, Bakhtin does not wish to undermine the legitimate and important pursuits of theory and science; nor does he deny the objectivity of scientific claims. ${ }^{46}$ What Bakhtin rejects is not theory, but theoretism, which is the view that the objective statements of the sciences and of logic represent and exhaust the ultimate reality. Theory, argues Bakhtin, cannot be the first philosophy, precisely because the deed, the actuality of human action and experience, is inaccessible to it. On the contrary, the deed, even though it is not objectively valid for all, should be the ground on which the first philosophy is to be built, because nothing stays out of its purview.

Bakhtin distinguishes between the fact and the content of a deed and between the given (dan) and the posited, or required (zadan), in it. I am now sitting here and writing. This is a fact for me. The words I am writing, the objects I see, etc. belong the content of this fact. All content is accessible to theory, but the fact of me acting upon it and experiencing it is not. All these objects and words are given as objective entities, but for me they are no mere objects and no mere words. What I am doing gives each of them a value: Here is the keyboard I am using, the mug with coffee I am reaching for, the disturbing noises from outside. The world for me is value-laden, or, to use Bakhtin's term (which is a modified version of a central term in neo-Kantian philosophy), posited. The given is objective, and is thus accessible to theory. The posited is not, because it depends on my choices and purposes.

A first philosophy grounded in the deed is blind to nothing. All objective content is included in deeds, my own and others' ${ }^{47}$ The world-as-posited already contains within itself the world-as-given. The shift to such a philosophy does not require us to give up on scientific progress. It merely demands a change in the philosophical order of priorities, precisely the change heralded by Kierkegaard: to put the individual above what is common to all.

But if we commit to theoretism, we end up with an unbridgeable chasm between the world of science and culture on the one hand and people's lived experience of the world on the other. This chasm was widely discussed in the early $20^{\text {th }}$ century as the divide between life and culture, ${ }^{48}$ and Bakhtin argues in effect that it is an artifact: the divide only appears

${ }^{46}$ TPA, 9-10; Sobr., 1: 14-15.

${ }^{47}$ See e.g., TPA, 28-29; Sobr., 1: 29.

${ }^{48}$ TPA 2; Sobr., 1: 7; Mikhail Bakhtin, "Art and Answerability," in Art and Answerability, 1-3; Sobr., 1: 56, and cf. Gogotishvili, in Sobr., 1: 384-86; Brandist, Circle, 18-19; Matvej Kagan, "Herman Cohen," trans. 
unbridgeable from a theoretist perspective. On the other hand, all attempts to bridge it that maintain a commitment to theoretism are liable to make an even graver error: to deny the very existence of the deed, of individual experience and action, worse still, to substitute a theoretical (e.g. psychological) transcription for the real thing.

This error is especially tempting for the human sciences, and it creates a problem not merely on the philosophical meta-level, but also for the sciences themselves. Linguistics serves as the Bakhtin Circle's favorite illustration of this point. Language is not, essentially, a phenomenon of the material world. It is rather part of human existence: "Historically language grew up in the service of participative thinking and performed acts". ${ }^{49}$ Attempting to study language as a closed system of objective phenomena, ignoring its role in actual deeds, leads to a basic error: misidentifying the object that linguistic science studies. ${ }^{50}$ This in turn leads to the inability of such a science to grasp the meaning of actual utterances, which Bakhtin and Voloshinov illustrate in several works. ${ }^{51}$

The terms "theory" and "theoretism" target a specific opponent: neo-Kantianism, especially of the Marburg school, which at the time was rapidly losing its status as the dominant school in German philosophy, and which was represented in Bakhtin's own social and intellectual environment by his close friend, Matvei Issaievich Kagan, a student of Hermann Cohen. To be sure, Bakhtin's attitude toward neo-Kantianism is a complex and controversial issue (which deserves a separate study; I will limit myself here to a brief remark). Bakhtin was clearly and significantly influenced by Hermann Cohen, Ernst Cassirer, and other neo-Kantian thinkers, and openly admitted it. ${ }^{52}$ Nevertheless, the central

Craig Brandist and David Shepherd, in The Bakhtin Circle: In the Master's Absence, ed. Craig Brandist, David Shepherd, and Galin Tihanov, 198; "German Kogen," in O khode istorii (Moscow: Iazyki slavianskoj kul'tury, 2004), 36, and cf. Galin Tihanov, "Culture, Form, Life: The Early Lukács and the Early Bakhtin," in Materializing Bakhtin: The Bakhtin Circle and Social Theory, ed. Craig Brandist and Galin Tihanov (London: Palgrave Macmillan, 2000), 43-69.

${ }^{49}$ TPA, 31; Sobr., 1: 31.

${ }^{50}$ Bakhtin, "Problem of Content," 292-93; Sobr., 1: 300-301.

${ }^{51}$ E.g., Valentin Voloshinov, "Discourse in Life and Discourse in Poetry. Questions of Sociological Poetics," trans. John Richmond, in Bakhtin School Papers, ed. Ann Shukman (Oxford: RPT Publications, 1983), 5-30; "Slovo v zhizni i slovo v poezii. K voprosam sotsiologicheskoj poetiki," Zvezda 6 (1926): 244-67; Mikhail Bakhtin, "The Problem of Speech Genres," in Speech Genres and Other Late Essays (hereafter LE), trans. Vern W. McGee (Austin: University of Texas Press, 1986), 60-102; Sobr., 5: 159-206.

${ }^{52}$ Bakhtin, Besedy s Duvakinym, 40; Brandist, Circle; "Two Routes 'to Concreteness' in the Work of the Bakhtin Circle," Journal of the History of Ideas 63 (2002): 521-37; "Bakhtin, Cassirer and Symbolic Forms," 
metaphysical claim of neo-Kantianism, that the world of phenomena is revealed by the theoretical sciences, which are in turn grounded in logic, ${ }^{53}$ was clearly unacceptable to Bakhtin, for the same reasons that Hegel's doctrine was unacceptable to Kierkegaard. Bakhtin greatly appreciated the achievements of neo-Kantianism, and adopted many neoKantian positions, but he also clearly stated that neo-Kantianism cannot claim the status of first philosophy, because the deed, human existence, remains utterly and necessarily outside its scope. ${ }^{54}$

But, like Kierkegaard before him, Bakhtin has more than a philosophical school in mind in his critique. First, within philosophy and the human sciences, theoretism is a label that he applies to practically all modern thought. ${ }^{55}$ Beyond the sciences, theoretism for Bakhtin is merely a symptom, one distinctly modern way of avoiding responsibility, of seeking, as he put it, "an alibi in being", of dissolving my acting self in objective content. ${ }^{56}$ In this Bakhtin's philosophy resembles that of other existentialists, from Kierkegaard on.

More than other forms of existential thought, however, Bakhtin's first philosophy specifically resonates with the radical shift in philosophical motivation that Kierkegaard has wrought. It questions the status of systematic knowledge about the world, which is in the end incommensurable with the life of the human individual, and proclaims individual human existence to be a more central philosophical concern than objective truth as such.

\section{One More Post-Hegelian Move and Two More Leaps}

So far I have focused on a central argument that the early Bakhtin inherited from Kierkegaard. But Bakhtin was also influenced by others. What I think makes Kierkegaard's influence on Bakhtin special is that Bakhtin adopted more than just a set of positions from Kierkegaard; he adopted an approach to philosophy, visible not only where he accepts Kierkegaard's points, but also where he goes beyond them and even against them.

As noted above, in Toward a Philosophy of the Act Bakhtin argues for a first philosophy grounded in the deed. Now, considering the individually unique nature of the deed, one wonders how any kind of philosophy can be grounded in it. Bakhtin's reply, in his early

Radical Philosophy, 85 (1997): 20-27; Brian Poole, "Bakhtin and Cassirer: The Philosophical Origins of Bakhtin’s Carnival Messianism,” South Atlantic Quarterly 97 (1998): 579-98.

\footnotetext{
${ }^{53}$ Kagan, "Herman Cohen," 203-4 and passim; "German Kogen," 40 and passim; Brandist, Circle, 16-18.

${ }^{54}$ TPA, 19; Sobr., 1: 21-22, and cf. Gogotishvili, in Sobr., 1: 457-60.

55 TPA, 7-30; Sobr., 1: 11-30.

${ }^{56}$ TPA, 40 ff; Sobr., 1: 38 ff.
} 
works, is that first philosophy provides a phenomenological description of the architectonics of individual existence as an event. Let me unpack this formula. Recall that from my unique perspective, and given my particular purposes and values, the world appears to me in a unique way. For Bakhtin this is not how the world merely appears; rather, it is a reality that can then be studied using the phenomenological method. ${ }^{57}$ The reality of the deed is populated not only by objects, but also by other individuals, with whom I interact, who matter to me. But there is one person crucially and necessarily missing from this reality: myself. Another can see me in the world, as I can see her, but I cannot see myself. "I love another, but cannot love myself; the other loves me, but does not love himself." 58 Bakhtin's first philosophy thus centers on self-other relations, which he refers to as "the event of being" (sobytie bytiia). The event of being has no pre-given structure that is the same for all, but it does have what Bakhtin calls an "architectonics": It is constructed and negotiated around three essential points of reference: I-for-myself, the other-for-me, and I-for-the other. ${ }^{59}$

The I-for-myself is not a subject in the traditional philosophical sense. It is a subject of experience and action but not a subject of reflection. ${ }^{60}$ To become a subject $I$ have to be supplemented by my own self-image, but this image is, again, unavailable to me directly. Only the other can see me as part of her world, can form a coherent image of me (and I can reciprocate: this is the other-for-me), and only from the other can I receive myself as a gift. ${ }^{61}$ My only access to an image of myself is through the eyes of the other. As a subject of reflection, as an object of self-knowledge, as part of the world's content, as a coherent unity, I belong to the other (I-for-the other).

This philosophical move, central to Bakhtin's thought, appears to be incompatible with the emphasis Kierkegaard puts on subjectivity, inwardness, and self-knowledge ${ }^{62}$ (although some passages in Kierkegaard's writings ${ }^{63}$ are closer to Bakhtin's position). Instead, if we search the history of philosophy for a claim that the subject is formed through the other, we will find it, ironically, in Hegel's philosophy. In part B of the Phenomenology of Spirit, Hegel claims

\footnotetext{
${ }^{57}$ TPA, 31-32; Sobr., 1: 31-32.

${ }^{58}$ TPA, 46; Sobr., 1: 43.

${ }^{59}$ TPA, 54; Sobr., 1: 49.

${ }^{60}$ AH, 138 ff; Sobr., 1: 206 ff.

${ }^{61} \mathrm{AH}, 100,143 ;$ Sobr., 1: $165 \mathrm{ff}$ (not included in the English translation), 175, 210.

${ }^{62}$ E.g. Kierkegaard, Journals vol. 5, 36-37.

63 E.g. Søren Aabye Kierkegaard, The Sickness Unto Death, trans. Howard Vincent Hong and Edna Hatlestad Hong (Princeton, NJ: Princeton University Press, 1980), 13-14.
} 
that consciousness first truly becomes self-consciousness by virtue of the recognition it receives from another consciousness. ${ }^{64}$

The similarity appears striking, but a closer look shows the crucial differences: according to Hegel, even though the need for recognition by others never disappears, self-consciousness eventually reaches unity. It becomes a subject of both perception and reflection, but already as a precondition for this, it becomes part of the unity of Spirit, of a "We". It then partakes in the greater unity of a social-political order, a system of science, a logical system of absolute knowledge - all these unities are eventually perceived as such from the point of view of the consciousness itself. Bakhtin, on the other hand, denies the possibility of unification from the individual's own viewpoint. If such a unity is possible, it is only possible from the point of view of the other. My image of myself, received from others, can never unite with the I-formyself.

Bakhtin states this point most clearly in his discussion of a situation in which one examines one's reflection in the mirror. ${ }^{65}$ Seemingly, this situation is a counterexample to one's inability to see oneself in the world, but, explains Bakhtin, only seemingly: "It is not that I look from the inside with my own eyes at the world, but rather I look at myself through the eyes of the world, through alien eyes; I am possessed by the other" ${ }^{66}$ The image I see in the mirror corresponds to how I might appear to another, and it is how another person would evaluate this image that mostly concerns me when I examine my reflection. On the other hand, the mirror image does not and cannot coincide with my inner sense of myself. My thoughts and feelings may be reflected on my face as it appears in the reflection, but this "external image of thought, feeling" $" 67$ is radically different from how I experience my thoughts and feelings from within. The resulting image of myself is bifurcated: "There is no naïve oneness of the external and internal here". ${ }^{68}$ The I-for-myself and the I-for-the other fail to merge.

Nor is it the case (as some neo-Kantians might argue) that, by obtaining ever new and better perspectives, I will, in time, approach a perception of myself as a whole. Such asymptotic approximation is possible, according to Bakhtin, when understanding another

${ }^{64} P S, \S \S 175-77$.

${ }^{65}$ AH, 32 ff; Sobr., 1: 112 ff; Mikhail Bakhtin, "Chelovek u zerkala” [“A Man at the Mirror”], Sobr., 5: 71.

66 "Ne ia smotriu iznutri svoimi glazami na mir, a ia smotriu na sebia glazami mira, chuzhimi glazami; ia oderzhim drugim" (Ibid.)

67 "Vneshnij obraz mysli, chuvstva" (Ibid.)

68 “Zdes' net naivnoj tsel'nosti vneshnego i vnutrennego" (Ibid.) 
(person, culture, utterance), but never does this asymptote approximate my view of myself. On the contrary, it leads away from it. ${ }^{69}$

Bakhtin's philosophical move can thus be viewed as post-Hegelian, that is, as based in many respects on Hegel (and his heritage in German philosophy), but rejecting the heart of Hegel's system. And it is specifically the Kierkegaardian kind of post-Hegelianism that we see here, one that rejects systematicity, the claim to unification, so long as the individual person's own perspective is concerned. This post-Hegelian stance not only characterizes Bakhtin's early philosophy, but runs through all the periods and subjects of his work. It remains a motivating philosophical principle for Bakhtin, a vector specifying the direction his work assumes, even as it absorbs a diverse array of other influences and sources. I will illustrate this briefly with a few examples. (The topics I touch on from this point on deserve a thorough discussion in a longer work; here I will only sketch the major themes in Bakhtin's oeuvre, as they relate to the topic of this paper, in crude lines).

Bakhtin's work on carnival studies a phenomenon that is in many ways the cultural equivalent of the I-for-myself. Bakhtin emphasizes that carnival actively involves the entire people, and thus does not allow the distance necessary for aesthetic perception, for the culture to form a holistic impression of it. ${ }^{70}$ Accordingly, carnival culture does not form an organic unity with the official culture of its day. Rather, it forms antibodies that make it possible to reject the inert discourse of official medieval culture. ${ }^{71}$ It forms a counter-current that can never be sublated into a higher cultural unity. True to its carnivalesque ancestry, the novel does not fit into a systematic theory of literary genres. ${ }^{72}$

The crown of Hegel's system is the integration of revealed religion in systematic philosophy. Bakhtin cries foul: "The only possible way of philosophically discussing systematic philosophy is by proceeding from within systematic philosophy itself." ${ }^{, 73}$ Bakhtin damns all major systematic philosophers with anthropomorphism. They all include in their seemingly systematic philosophy traces of the specifically human way of perceiving the

${ }^{69}$ E.g., Mikhail Bakhtin, "Response to a Question from the Novy Mir Editorial Staff”, in LE, 3-7; Sobr., 6: 453-57.

${ }^{70}$ Rab., 7; Sobr., 4(2): 15. On Hegelian themes in Rab. see Galin Tihanov, The Master and the Slave: Lukács, Bakhtin, and the Ideas of Their Time (Oxford: Clarendon Press, 2000), 271-91.

${ }^{71}$ Mikhail Bakhtin, "From Notes Made in 1970-71," in LE, 132-33; Sobr., 6: 389.

72 Mikhail Bakhtin, "Epic and the Novel," in The Dialogic Imagination: Four Essays, trans. Caryl Emerson and Michael Holquist (Austin: University of Texas Press, 1981), 3-6; Sobr., 3: 608-11.

${ }^{73}$ Lect., 212; Sobr., 1: 332. 
world. ${ }^{74}$ But it is precisely this human way of perceiving the world that is the only possible starting point for a philosophy of religion, for religion itself. ${ }^{75}$

Many other Bakhtinian themes center on the representation of the human being as unfinalizable, as unable to form a coherent whole, from the point of view of the second person. Before discussing specific examples, I should briefly explain how such representation is possible in Bakhtin's philosophical framework. Recall that Kierkegaard describes an individual's move from one mode of existence to another as a leap, that is, as impossible from the individual's position within the former mode. Bakhtin, while not using the same term, fully embraces this description. ${ }^{76}$ As Bakhtin argues at length in toward a Philosophy of the Act, a person seeking to avoid answerability by only recognizing content as real has to make a leap, precisely Kierkegaard's leap of decision, to recognize her own existence, the actual and irreversible nature of her deeds. This is an impossible feat for her to perform from her own perspective, since an outlook that only recognizes the reality of content (theory) has no access to the deed and no ability to account for it. However, having embraced her existence and freedom, the individual now has one more leap to make to attain true peace of mind, equivalent to Kierkegaard's leap of faith. Despite her inability to perceive herself as a whole and despite her responsibility and guilt, she has to trust the other (and God in particular) to do the impossible: to see her as a coherent whole, and to forgive her. ${ }^{77}$

But on top of these two leaps, performed from the first-person perspective, Bakhtin also proposes a similar progression, involving two leaps, from the point of view of the other. In the first leap, the other (author, scholar, reader or listener) forms a coherent view of her object as a whole (the perception of an individual or a literary character as an aesthetic object, or the view of a field of natural or human phenomena as an organic, rather than a mechanical, unity). This requires the other to forego any presence in the perceived and described whole, to commit "absolute self-exclusion". ${ }^{78}$ (This is to some extent analogous to the movement of resignation, which is an essential condition for performing the leap of faith according to Kierkegaard). But following this, the road is opened to another, higher, impossible

\footnotetext{
${ }^{74}$ Lect., 209-18; Sobr., 1: 330-39.

${ }^{75}$ Lect., 207-9; Sobr., 1: 328-30.

${ }^{76}$ Most explicitly in Lect., 209; Sobr., 1: 330.

${ }^{77}$ Lect., 207-9; Sobr., 1: 328-30; AH, 138-50; Sobr., 1: 206-15.

${ }^{78}$ TPA, 76; Sobr., 1: 68.
} 
achievement - representing the unfinalizability and freedom of the human object of description.

Bakhtin devoted much of his work to studying the historical development of the cultural forms that prepare for this last leap. The representation of the human body in grotesque imagery avoids the aesthetic completeness of the human image, ${ }^{79}$ and instead portrays the human being's open and active points of contact and merger with the world. An intellectual equivalent appears in Menippean satire, whose characters openly discuss their most fundamental beliefs on the thresholds of heaven and hell. ${ }^{80}$ The novel brings into the purview of literary culture and language, and further develops, hybrid forms of discourse, which prevent the closing-off of the speaker's intention. The most striking example is double-voiced discourse of the active type, in which the speaker's discourse is permeated with an anticipation of her audience's response. ${ }^{81}$ This line of development culminates in Dostoevsky, who finally accomplishes the leap and creates a polyphonic novel, in which the characters are represented in all their ethical freedom. But the leap again involves resignation: Dostoevsky has to forgo any use of his surplus of vision as an author, i.e. his ability to represent his characters beyond the reach of their own purviews, his privileges as an author. ${ }^{82}$

The same progression of two leaps also appears in Bakhtin's discussions of language and of the philosophy of the human sciences. In his (unfinished) article "The Problem of Speech Genres", written in the early 1950s, Bakhtin insists on the importance of perceiving an utterance holistically for understanding it. The meaning of an utterance as a whole cannot be reduced to the meanings of the individual words and sentences composing it, and only through this holistic meaning does language come into contact with the world and with speakers and listeners. ${ }^{83}$ But then Bakhtin also insists that this holistic meaning of the utterance is never final, that the true meaning of an utterance is given in the ever-changing chain of dialog, in which it is but one link, and therefore that this meaning changes with every response the utterance receives. ${ }^{84}$ Similarly, the human sciences have to form a holistic impression of their object of study, legitimately abstracting away from the essential ethical

\footnotetext{
${ }^{79}$ Rab., 315-18; Sobr., 4(2): 339-42.

${ }^{80}$ PDP, 101-80; Sobr., 6: 115-202.

${ }^{81}$ PDP, 195-99; Sobr., 2: 92-96, 6: 218-22.

${ }^{82}$ PDP, passim; Sobr., 2: 7-175, 6: 7-300.

${ }^{83}$ Bakhtin, "The Problem of Speech Genres"; Sobr., 5: 159-206.

${ }^{84}$ Bakhtin, "Notes 1970-71," 145-46; Sobr., 6: 410.
} 
freedom of the human beings that form this object; they have to become theories. ${ }^{85}$ But this is merely the first step. The second step is to turn scientific inquiry into a form of dialog with the object of study, thus recognizing its unfinalizability as a person: "The being of the whole, the being of the human soul, freely revealing itself to our act of knowledge, cannot be bound by this act in any significant aspect." 86

\section{Conclusion}

In this essay I argued that Kierkegaard's philosophy was a central influence on Bakhtin. But not all influences were created equal: some are superficial, others run deep. That is certainly true in Bakhtin's case. From some he merely borrowed terms, others raised problems and developed concepts that he dealt with extensively, others still had a much deeper influence on him, but essentially as adversaries - he adopted many principles and ideas from them, while rejecting the very core of their philosophical systems, as was the case with Hegel and (I would argue) the Marburg neo-Kantians.

But there is, Bakhtin claims, a level of response higher than disagreement: agreement. ${ }^{87}$ On this higher level, for Bakhtin, we find the philosophy of Søren Kierkegaard. Bakhtin not merely adopted the reversal of metaphilosophical priorities that Kierkegaard called for, but made it his own, developed it in new and unexpected directions. Those who fail to realize Kierkegaard's influence will find it difficult to see the true originality of Bakhtin's early philosophy, to understand what he has in mind when he talks about the actuality of concrete individual experience and action. ${ }^{88}$ Once we do recognize this influence, and read Bakhtin's works with it in mind, we can see the importance of his work. Bakhtin's original choice to study not only human existence as such, but also its cultural representation, allowed him to develop conceptions of language, literature, and culture that are truly grounded in actual individual existence in all its concreteness, without theorizing this concreteness away.

Paradoxically, then, Kierkegaard's influence on Bakhtin is the sort of influence that explains the originality of a thinker no less than his indebtedness to others.

${ }^{85}$ Bakhtin, "Problem of Content," 292-93; Sobr., 1: 300-301.

86 "Bytie tselogo, bytie chelovecheskoj dushi, raskryvaiuscheesia svobodno dlia nashego akta poznaniia, ne mozhet byt' sviazano etim aktom ni v odnom suschestvennom momente” (Bakhtin, "K filosofskim osnovam gumanitarnykh nauk" [“Towards the Philosophical Foundations of the Human Sciences"], in Sobr., 5: 8).

${ }^{87}$ Mikhail Bakhtin, “The Problem of the Text," in LE, 121; Sobr., 5: 332.

${ }^{88}$ Cf. Brandist, Circle, 39-40; "Two routes". 